\title{
Chapter 6 \\ Towards a Global Real Estate Market? Trends and Evidence
}

\author{
Laurent Clerc
}

\section{Introduction}

Several central banks and international institutions have recently ranked the risk of a snapback in interest rates at the top of their financial risk assessment. To some extent, the current situation presents some similarities with the period that preceded the global financial crisis of 2007-2008. In particular, it has been characterised in many countries by a sharp increase in residential house prices for almost 10 years, at a time when household debt levels are already high and certain countries have not yet completed the deleveraging process begun in the aftermath of the crisis. A sudden tightening of financial conditions could thus result in a strong decline in house prices and a significant increase in defaults in the household sector.

The dynamics of housing markets are a crucial determinant of financial stability as house price booms are generally closely related to credit and monetary developments and thus to financial firms' balance sheets. Historical evidence indeed shows that a significant number of banking crises were preceded by the bursting of house price bubbles (Reinhart and Rogoff 2008).

Over the past few years, there has been an increasing focus on the globalisation of financial markets, and more recently on housing markets. There is already compelling evidence that capital flows resulted in inflationary pressures and asset price booms in Latin America in the 1980s and 1990s, in emerging Asia in the late 1990s and, more recently, in the run-up to the financial crisis. Attention has now shifted to

The views expressed in this paper are those of the author and do not necessarily reflect the position of the ACPR, the Banque de France or the Eurosystem.

\section{Clerc $(\bowtie)$}

Autorité de Controle prudentiel et de résolution, Direction d'étude et d'analyse des risques,

Paris, France

e-mail: laurent.clerc2@acpr.banque-france.fr 
the role of global financial conditions, and in particular of US monetary policy, in shaping asset price developments, and in particular house prices.

The idea that housing markets are exposed to the global economy is not completely new, but the evidence has mainly centred on "world" or "global" cities. These cities are hubs in a global network where global control functions are produced by global companies in core financial, business and economic activities.

In this paper, I analyse the extent to which the process of financial globalisation has become generalised and has been playing a role in the recent dynamics of housing markets. I find some evidence of increased synchronisation across housing markets for a sample of 18 OECD countries. The evidence is particularly clear for the period that preceded the financial crisis and points to a growing role of global financial conditions. However, national housing market characteristics tied to financial contracts, fiscal incentives and housing supply continue to play a significant role in shaping house price cycles, in particular their amplitude. As a result, national authorities still have significant leeway to insulate their housing markets from global fluctuations, in particular thanks to macroprudential policy.

The rest of the paper is organised as follows. Section 2 provides some evidence of the increasing role played by global factors in explaining the synchronicity of housing cycles across countries and large cities. Section 3 shows that the domestic structural features of housing markets remain important and explain some differences across countries, in particular regarding the dynamics and amplitude of housing cycles. Section 4 concludes by looking at the policy implications and the role of macroprudential policy in preventing systemic risks stemming from housing markets.

\section{The Increasing Synchronicity in House Prices Across Countries}

\subsection{Towards a Global Real Estate Market. ..?}

Figure 6.1 shows the developments and the trends in real house prices in 18 OECD countries since 1975. Several stylised facts emerge.

1. Real house prices have generally increased over the period 1975-2018. In most countries, prices have at least doubled if not tripled in real terms, with a couple of countries, such as the United Kingdom and Ireland, experiencing even sharper increases (five to six fold). ${ }^{1}$

2. Only four countries out of 18 have experienced declining trends over the period: Germany, where real house prices fell steadily in the aftermath of German

\footnotetext{
${ }^{1}$ In most cases, I estimated exponential trends and used polynomial trends for Spain, Sweden and Switzerland.
} 

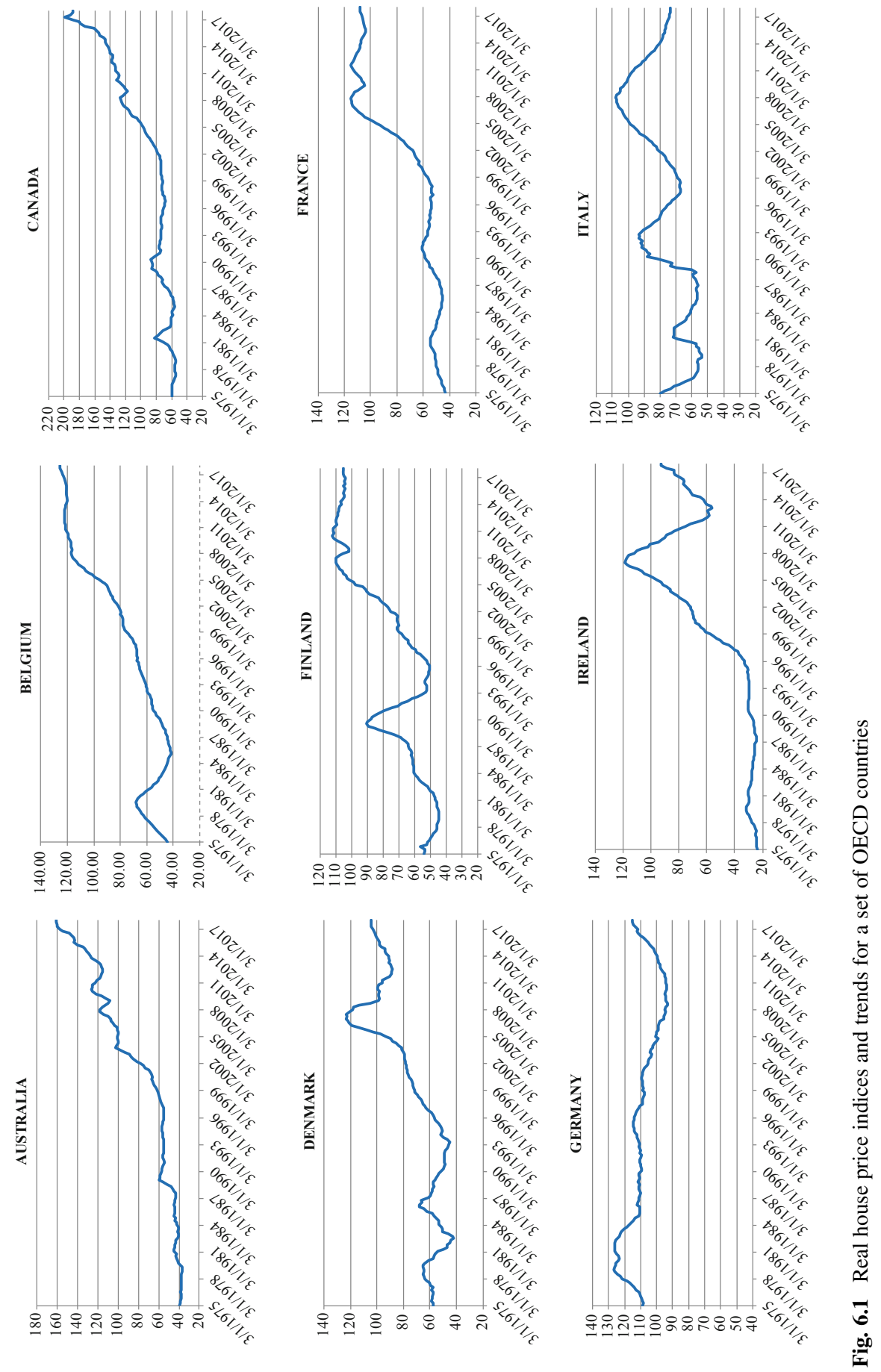

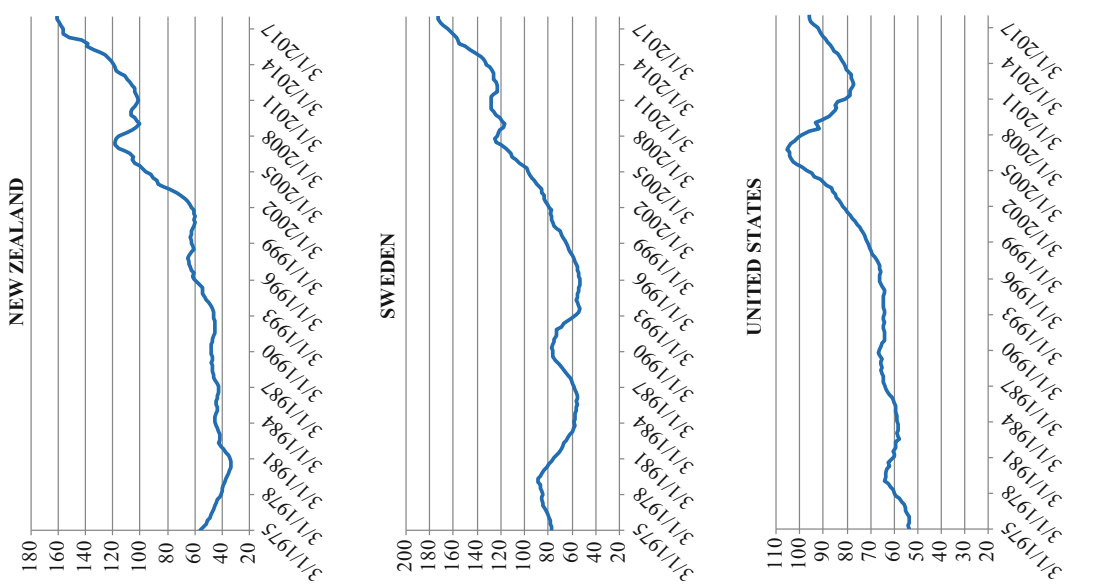

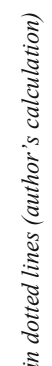
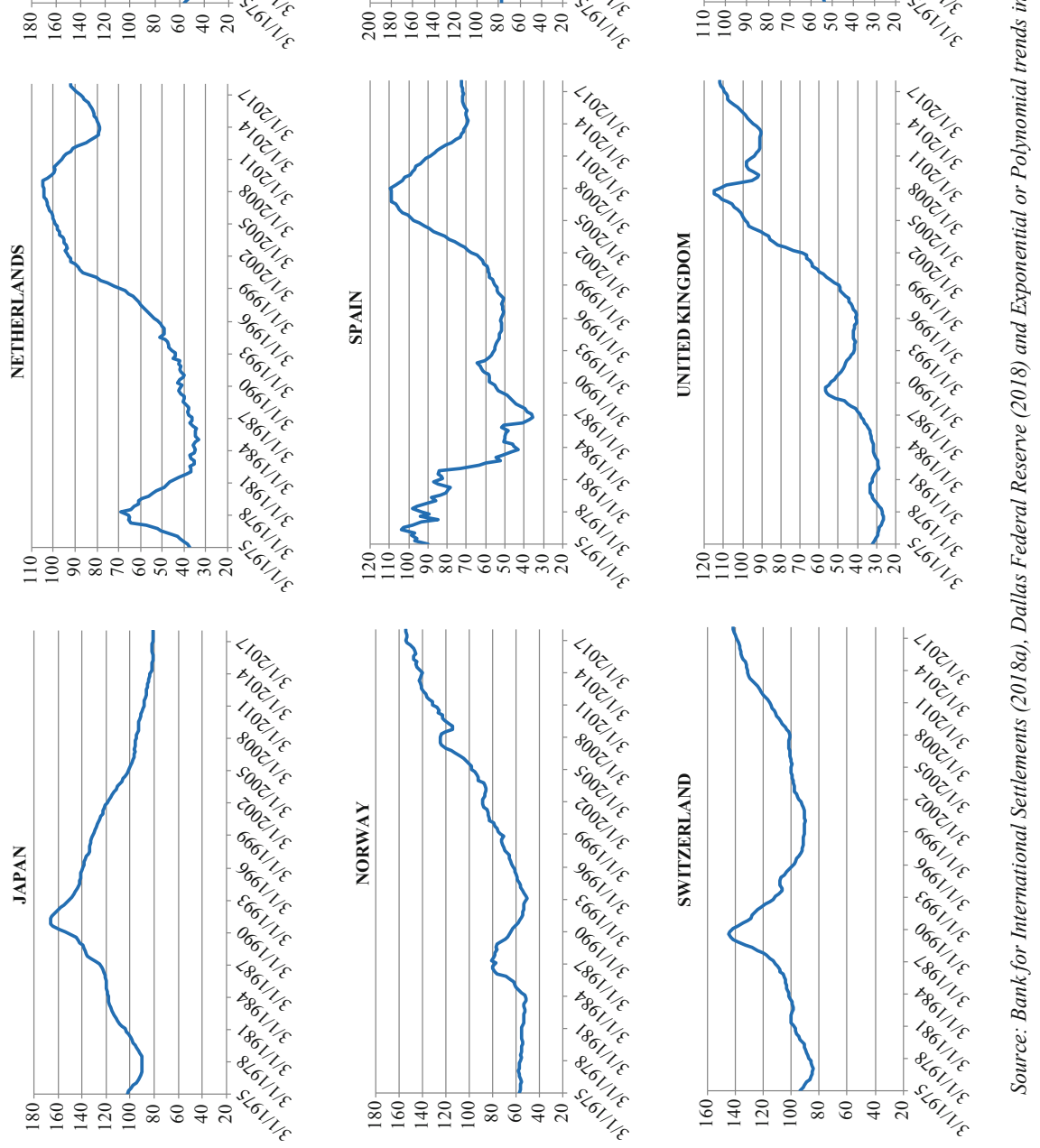

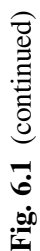


reunification and have picked up significantly only recently; Japan, which experienced a massive housing bubble from 1977 to 1991, and has not yet recovered from the bursting of that bubble; Sweden and Spain, which began the period with a significant correction in real house prices, before experiencing sharp increases in the mid-1990s: the increase has held steady so far in Sweden, but proved unsustainable in Spain, which experienced a second dramatic price correction that is still ongoing.

3. Beyond these overall upward trends, several housing cycles can be observed, which differ in terms of frequency. The number of peaks is 3 for half of the countries over the sample period; 5 countries experienced more frequent cycles (Australia, New Zealand and Sweden have the highest frequencies, followed by France and Canada).

4. Some countries have seen only one or two housing cycles over the period, which have proved costly and destabilising for their economies, as in the case of Japan, Switzerland, Ireland and the Netherlands.

5. The amplitude of the housing cycles also differs across countries. Using the de-trended series to extract the cycle component, the amplitude measured by the standard deviation of this cycle component relative to the trend is huge for some countries: for instance, for Ireland and the Netherlands, it is greater than $25 \%$, while for Spain and Japan it is higher than or close to $20 \%$.

6. Despite this heterogeneity across countries, the boom episode starting in the mid-1990s is common to almost all countries, with the exception of Germany and Japan. It is also far more pronounced than previous booms, and significantly longer, ending almost everywhere with a sharp correction in real house prices, in around 2007 or 2008 , that is to say almost $10-15$ years after it started. This synchronicity both in the emergence of the bubble and its bursting provides initial evidence of the role played by global common factors in shaping house price dynamics.

To better characterise this synchronicity across countries, I compute diffusion indices (see Fig. 6.2). First, exploiting the persistence of house price developments, I compute indicator variables for each country, which take the value 1 if the quarterly increase in house prices is strictly positive and the value 0 otherwise. I then sum up these indicator variables across countries for each date to generate a time series. The corresponding index is presented in panel a) of Fig. 6.2. It shows the number of countries simultaneously experiencing a quarterly increase in real house prices at a given date.

Four real house price cycles show up in the data, a first one ending in 1981, a second ending in 1992, a third ending in 2008, and a last one which is still ongoing. These cycles are characterised by the following features:

First, housing booms tend to develop gradually and spread across countries, with almost all countries in the sample experiencing at some point similar periods of real price increases (up to 17 countries out of 18 at peaks). The current ongoing episode, which is tending to stabilise, seems less widespread than the two previous ones, but has already lasted for 10 years. 


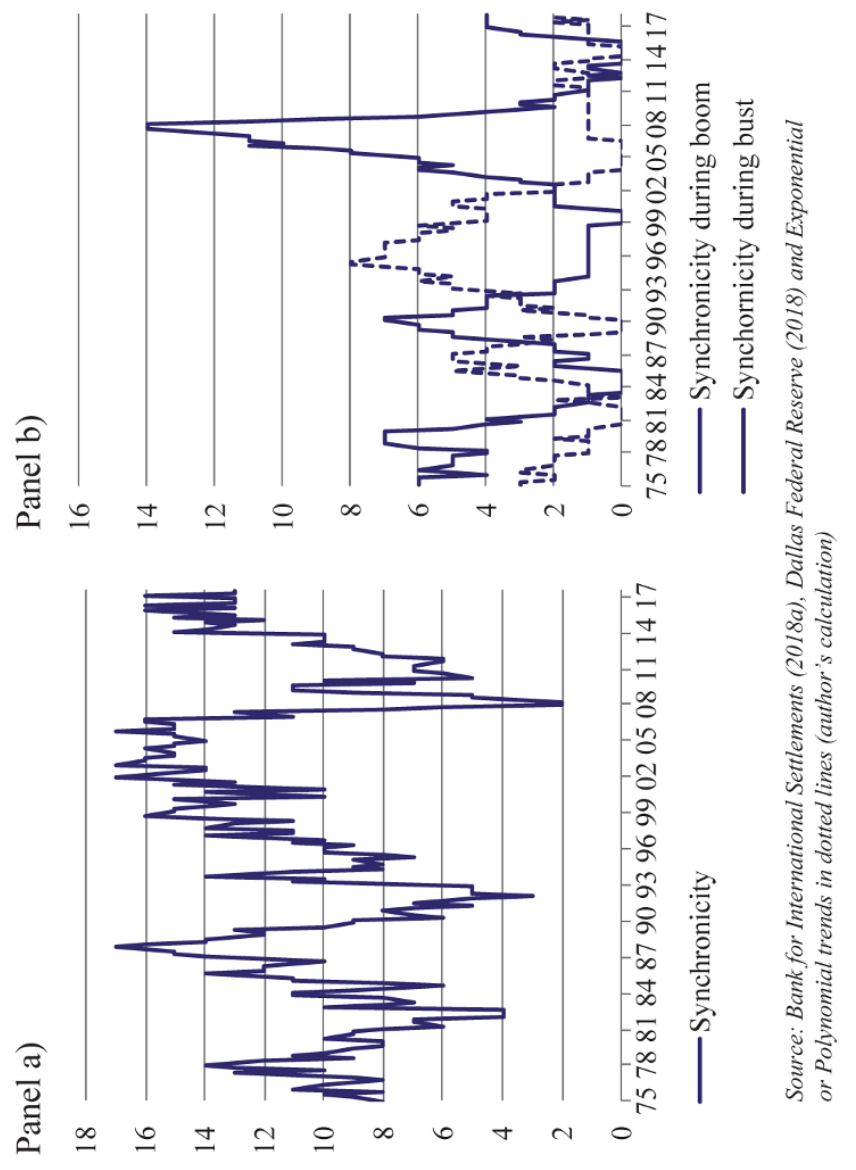

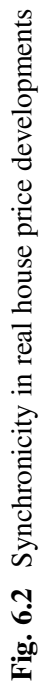


Second, the length of the episodes tends to increase over the sample period, with the one preceding the global financial crisis proving particularly long.

Third, these cycles tend to be asymmetric, with the periods of price increases generally lasting significantly longer than the periods of decrease. The latter tend in addition to be abrupt and huge, as in 2008 where the fall in real house prices occurred almost simultaneously in all sample countries (except 2).

Panel b) of Fig. 6.2 provides additional information on the amplitude of housing cycles in particular in periods of booms and busts. I compute time diffusion indices for each country, which take the value 1 when de-trended real house prices exceed their historical trend by more than one standard deviation (characterising "boom periods") or are more than one standard deviation below trend ("bust periods"). I then sum up these variables across countries, disentangling "boom" and "bust" periods.

Starting with "booms", Fig. 6.2 panel b) highlights the singularity of the episode preceding the financial crisis. Whereas the two previous cycles as well as the current one tend to involve a relatively limited set of countries, the one starting in the mid-1990s affected almost all sample countries (14 out of the 18 experienced a simultaneous "boom" period). Using a more stringent definition of excessive real house prices (that is a gap of more than 2 times the standard deviation) roughly halves the number of countries simultaneously experiencing a boom (to around 3 or 4 countries, usually), but there were nonetheless 8 countries in that situation in the run-up to the financial crisis.

Turning to "bust" periods, a different picture emerges. Fig. 6.2 panel b) shows in particular that the immediate period following the bursting of a housing bubble is characterised by very different patterns across countries. Here again, the episode ending in 2008 stands out and illustrates the variety of policy responses and their impact on real price developments across countries.

\section{2 ... Or the Growing Importance of World Cities?}

Housing markets are notoriously heterogeneous at the national level, with prices generally proving higher in big cities due to a combination of lack of space and migration towards those areas where economic and financial activities are located. One question that arises is the extent to which house price developments at the country level reflect the role of big cities, in particular capitals, in shaping price dynamics. In addition, big cities are more likely to be influenced by global factors due to their global connections and their greater exposure to financial globalisation.

The influence and role of big cities are nothing new in history and geography. In Medieval Europe, for instance, large trade centres were already highly interconnected, as companies generally operated in foreign cities where they did business via trusted agents-usually family members (Taylor 2016). Those links were even further formalised through explicit commercial agreements as in the case 
of the Hanseatic cities up to 1648. Historians like Braudel (1984) and Wallerstein (1974) trace a first wave of globalisation during the 1450-1650 period, with the emergence of "world-empires" (see for instance Wallerstein 1974) and where the connections between cities stemmed from different forms of monopolistic control of production, trade and finance. A second wave of globalisation was triggered by the expansion of European countries that culminated at the end of the nineteenth century, a period known as "European imperialism". According to Taylor (2016), this globalisation process was accompanied by an unprecedented shift towards urbanisation, with big cities being "a crucial focus of the infrastructure enabling the new globalisation that included railways and telegraphs within countries and steam shipping and ocean cable networks between countries worldwide". A third wave of globalisation took place after World War II, with the expansion of multinational corporations mostly led by American firms.

Table 6.1 presents some selected statistics and rankings for capitals or big cities for a range of indicators illustrating economic or financial activity and quality of life.

For instance, the Global Financial Centres Index (GFCI) is a ranking of the competitiveness of financial centres based on over 29,000 financial centre assessments. The ranking is an aggregate of indices from five key areas: "Business environment", "Financial sector development", "Infrastructure factors", "Human capital", "Reputation and general factors". It is comparable to the ATKearney index, which ranks cities according to 5 areas: "Business activity", "Human capital", "Information and Exchange", "Cultural experience" and "Political engagement". An additional dimension is captured by the Mercer's Quality of Living ranking which establishes a ranking of the most liveable cities in the world, taking into account soft factors like the quality of leisure time or cultural diversity but also easy access to transportation, reliable electricity or drinkable water. This index is supposed to play an important role when multinationals decide where to establish locations abroad and send expatriate workers.

The table also includes Airbnb listings. Airbnb is the most popular supplier of home sharing on peer-to-peer markets. Empirical evidence suggests that an increase in listings is associated with an increase in both rents and house prices, the latter being in addition larger than the former (see for instance Barron et al. 2017). Homesharing platforms would cause landlords to switch from supplying the market for long-term rentals to supplying the short-term market. Occupancy tax avoidance would be another reason for the development of home sharing platforms.

Finally, the table is completed with an index computed by the Gottlieb Duttweiller Institute (2017) which attempts to rank cities according to their connections in the digital world (based on the total number of connections on English Wikipedia, Twitter feeds and the World Wide Web as accessed by Google), while the last column provides a measure of capital flows or international investment for the top 10 cities in the world.

These indicators are compared to changes in real house prices during the period 2013 and 2017 (column 1) and to the UBS Global Real Estate Index which gauges the risk of a property bubble according to the pattern of indicators accounting for the 


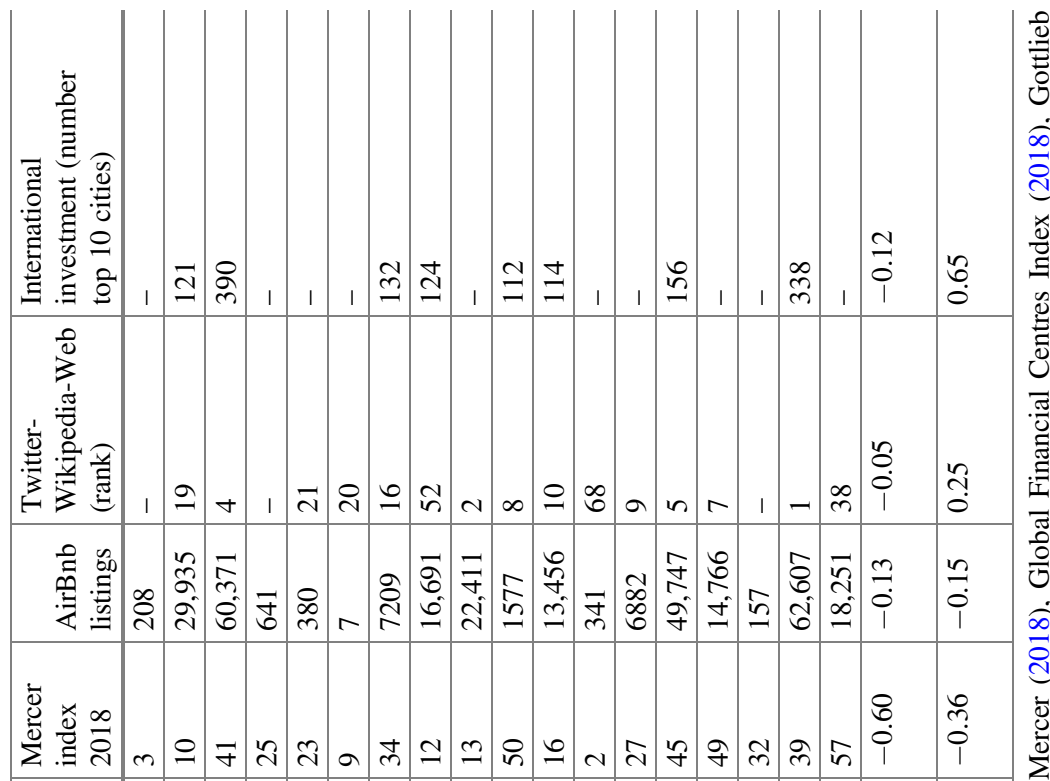

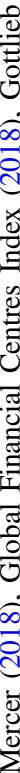

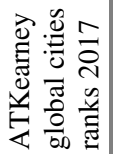

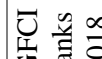

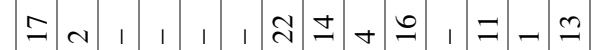

$m \mid$\begin{tabular}{l|l}
$n$ & 0 \\
0 & $\dddot{0}$
\end{tabular}

家

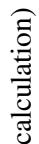

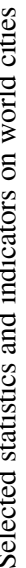

宽

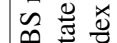

$\ddot{d}$

을

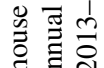

晃

$\begin{array}{lll}\stackrel{\overbrace{}}{0} & \infty \\ 0 & \infty \\ 1 & 0\end{array}$

훙 
decoupling of local prices from local incomes and rents, or indications of excessive lending and construction activity.

While the ranking of cities is not necessarily fully consistent across the board, the table first reveals that the big cities in our sample countries almost all belong to the top world cities according to various criteria, with a significant number featuring in the top 20. Second, these rankings are usually not related to the size of the city. The different indicators make it clear that capitals or big cities belong to a network of highly interconnected cities.

The link between these different indicators and the average real house price growth rate over the period 2013-2017 is not clear and the correlation coefficients are not fully consistent across the board. By contrast, all of these indicators are highly and positively correlated with the UBS bubble index, but the Mercer index, which is expected as excessive house prices may deteriorate the quality of live in a specific city. Finally, we do not find evidence of a positive correlation between Airbnb listings and price developments or the UBS bubble index in our sample.

Figure 6.3 provides additional information by comparing real house price developments in these big cities to the developments taking place in their respective countries. The figure shows that real house prices at the city level tend to evolve in line with real prices observed at the country level, with a tendency to overshoot, sometimes significantly, national developments, as in Amsterdam, where house prices overshoot the average price increase in the Netherlands by a factor of 15 .

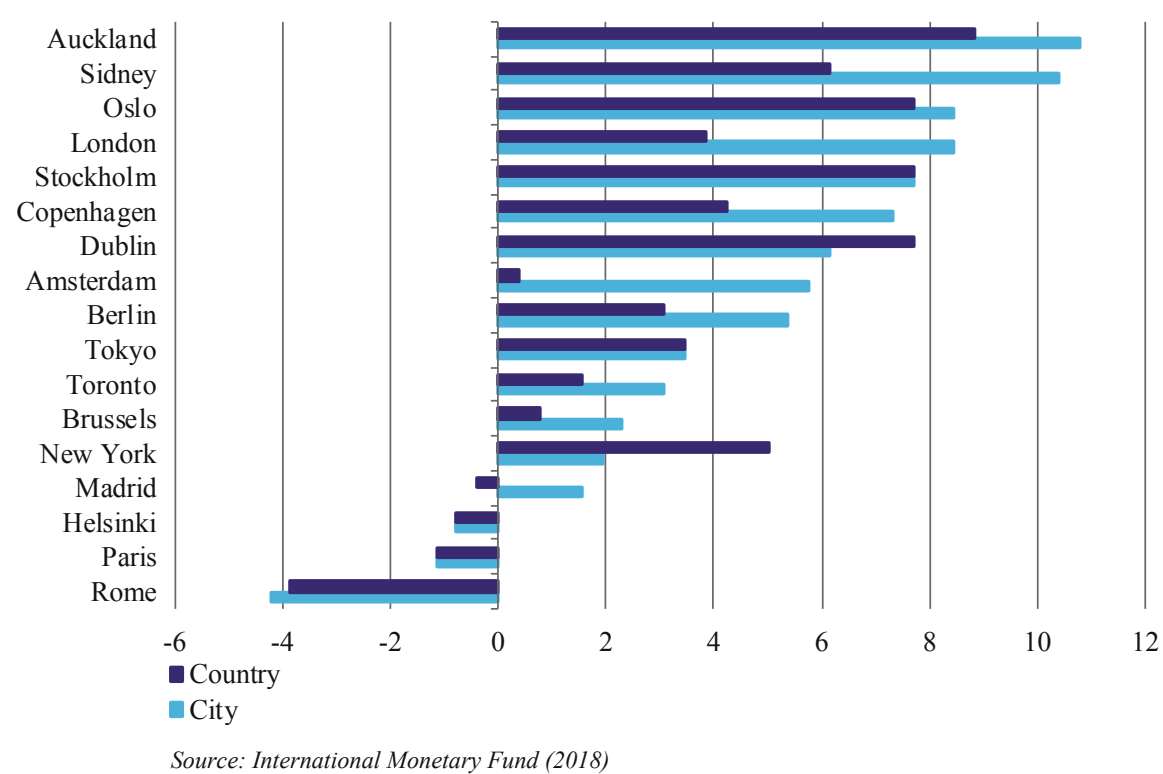

Fig. 6.3 Average annual real house price growth in top cities and their respective countries 


\section{House Price Determinants}

\subsection{Synchronicity: The Role of Global Factors}

In a previous paper with Borgy et al. (2014), I explored the ability of a system of early indicators to detect ex-ante the build-up of financial imbalances, in particular in housing markets, for a similar set of OECD countries. The three most robust and powerful early warning indicators to detect costly ${ }^{2}$ real house price booms are real interest rates (both short and long) and real stock prices. These indicators can be combined into financial conditions indices. These variables, in particular long-term rates and stock prices are particularly influenced by global factors.

The increasing synchronisation of global financial cycles has received a lot of attention over the past 3 years. In a seminal contribution, Miranda-Agrippino and Rey (2015) demonstrated the existence of a common movement in global asset prices in international equity and bond markets.

Rey (2015) highlights in particular the central role played by US monetary policy which tends to spread through the financial system by impacting on the balance sheets of global banks, which in turn affects credit conditions and developments in credit supply.

Extending this approach to housing markets, Luo and Ma (2017) find that, for an average country, the implied global housing market risk premium is the most important determinant of housing market volatility, especially in the period preceding the financial crisis in 2007-2008. This global premium appears to be strongly influenced by US monetary policy, both through the risk-taking and the credit channels.

This evidence is shared by the recent IMF Global Financial Stability Report (2018), which devotes its Chap. 3 to house price synchronisation and finds that global financial conditions provide a convincing explanation for the synchronicity of housing markets, both at the city and country levels.

Figure 6.4 shows the evolution of the financial conditions indices provided by the IMF since 1991 for most sample countries. As can be seen, while financial conditions may vary across countries, their pattern is very similar and closely mirrors that of the US financial conditions index. Comparing Figs. 6.2 and 6.4 also makes it clear that favourable or accommodative financial conditions tend to be associated with periods of house price increases and booms, while the tightening of these financial conditions is concomitant with house price decreases or even busts, as can be seen in particular around 2007 and 2008.

Figure 6.4 also shows that the volatility of financial conditions indices differs significantly across countries. The first panel, which displays the highest volatility across countries, consists mostly of Anglo-Saxon countries.

\footnotetext{
${ }^{2}$ Costly booms refer to booms in real estate prices which are followed by severe recessions, that is periods of at least 3 years in which overall real GDP growth was at least 3\% points lower than potential output growth.
} 

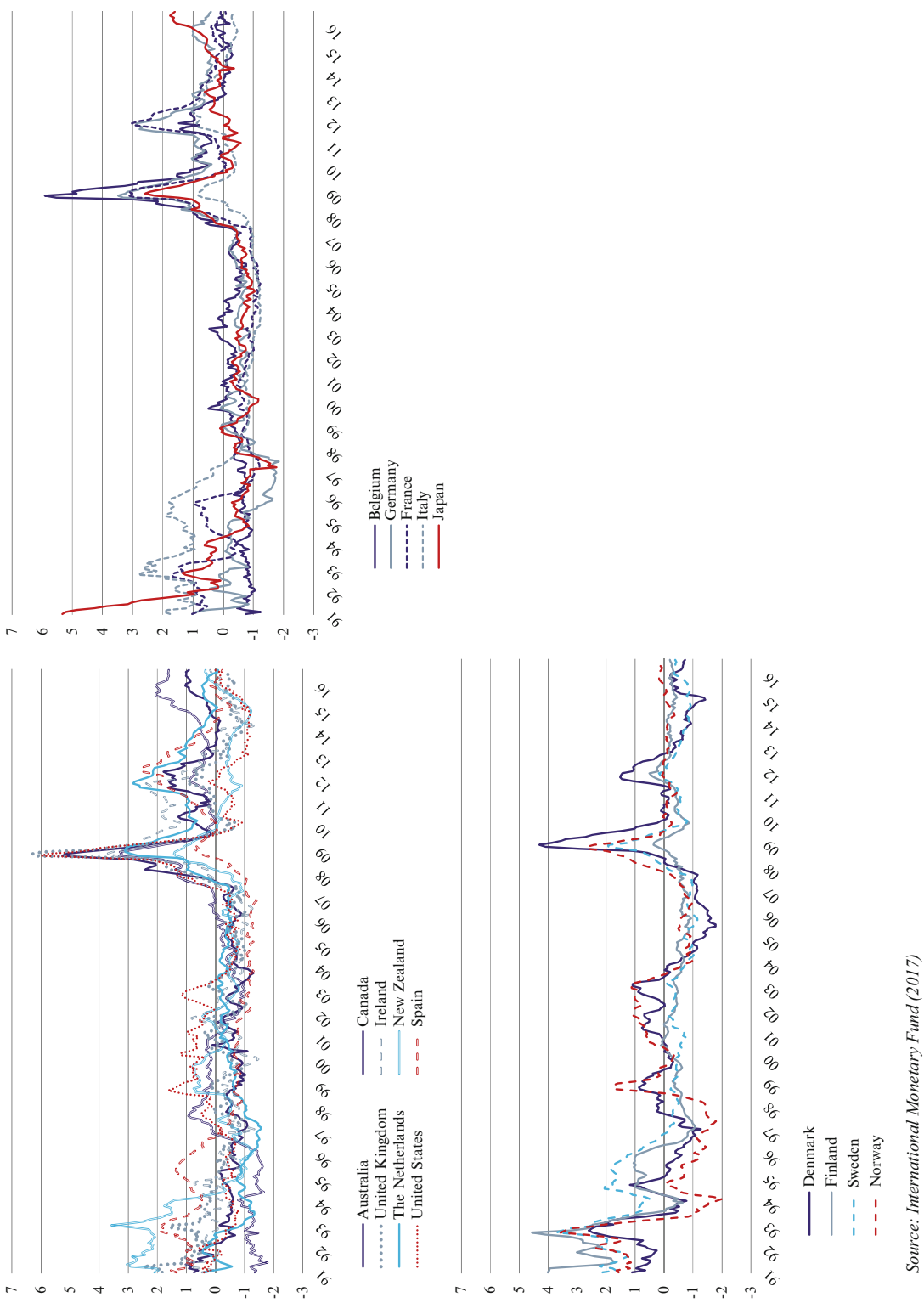
The housing markets in these countries share similar features, in particular the ability of households to cash in their mortgage equity, which can alleviate their credit constraints. The top-right panel, which groups together continental Europe and Japan, is characterised by an absence of mortgage equity withdrawals and in general the dominance of fixed mortgage rates. The variation is lower than in the previous set of Anglo-Saxon countries. Finally, the bottom left panel groups together certain Nordic countries which all experienced a severe housing market correction at the beginning of the 1990s, and which tend to behave similarly over the sample period, again with less variation across countries than in the first group.

These differences in developments tend to emphasise the role of domestic features as amplifiers of house price dynamics.

\subsection{Local Amplifiers}

National features, related to the nature of financial contracts, fiscal incentives and housing supply, play a very important role in determining the functioning of housing markets. Table 6.2 presents selected national market characteristics.

A first important feature differentiating countries is the existence of mortgage equity withdrawals (MEW) that is the possibility for households to cash in their

Table 6.2 Selected national housing market characteristics

\begin{tabular}{l|l|l|l|l|l|l}
\hline & $\begin{array}{l}\text { SDEV } \\
\text { house price } \\
\text { cycle }\end{array}$ & MEW & $\begin{array}{l}\text { Refinancing } \\
\text { fee free } \\
\text { repayment) }\end{array}$ & $\begin{array}{l}\text { Prevailing } \\
\text { type of } \\
\text { interest rate }\end{array}$ & Max LTV & $\begin{array}{l}\text { Typical } \\
\text { term to } \\
\text { maturity }\end{array}$ \\
\hline Australia & 10.5 & Yes & Limited & Variable & 100 & 25 \\
\hline Belgium & 16.6 & No & No & Fixed & 100 & 20 \\
\hline Canada & 14.3 & Yes & No & Mixed & 95 & 25 \\
\hline Denmark & 18.0 & Yes & Yes & Mixed & 80 & 30 \\
\hline Finland & 15.6 & Yes & No & Variable & 80 & 20 \\
\hline France & 14.2 & No & No & Fixed & 100 & 20 \\
\hline Germany & 5.7 & No & No & Fixed & 80 & 15 \\
\hline Ireland & 29.1 & Limited & No & Mixed & 100 & 40 \\
\hline Italy & 15.2 & No & No & Variable & 80 & 22 \\
\hline Japan & 19.5 & No & No & Mixed & 80 & 30 \\
\hline Netherlands & 25.4 & Yes & Yes & Fixed & 125 to 100 & 30 \\
\hline New Zealand & 17.4 & Yes & - & Variable & 85 & 30 \\
\hline Norway & 15.0 & Yes & No & Variable & 85 & 20 \\
\hline Spain & 24.0 & Limited & No & Variable & 100 & 20 \\
\hline Sweden & 11.4 & Yes & Yes & Variable & 95 & 45 \\
\hline Switzerland & 13.9 & Yes & - & Fixed & 80 & 20 \\
\hline UK & 16.6 & Yes & Limited & Variable & 110 & 25 \\
\hline US & 9.4 & Yes & Yes & Mixed & 100 & 30 \\
\hline So & & & & &
\end{tabular}

Source: Cerutti et al. (2017) and ESRB (2015) 
mortgage equity. This is an important mechanism through which the financial accelerator mechanisms, highlighted by Bernanke et al. (1999) or Kiyotaki and Moore (1997), can be activated and feed boom-bust dynamics.

With such a mechanism in place, households can relax their borrowing constraints and increase their consumption spending, in particular to improve their house's value, in periods of house price booms. Using the value of their house as collateral, they can borrow more and further relax their borrowing constraints. Such a mechanism is absent in countries where the value of the house is based on historical costs in debt contracts.

In the sample, for countries where MEW is possible, the amplitude of the cycle is on average $3 \%$ points greater than in countries where it is not implemented.

The third column shows whether or not it is possible to refinance housing debt in each particular country without incurring a fee. This facility in not widespread and tends to play a limited role. However, the low level of interest rates that has resulted from very accommodative monetary policies across the world, coupled with fierce competition amongst lenders, have dramatically reduced these fees, allowing households to massively renegotiate the terms of their mortgage contracts in the recent period, at little or no cost.

Column 4 shows the prevailing type of interest rate in mortgage debt contracts. It links mortgage rates to key short-term interest rates in economies where these mortgage rates are adjustable, and to long-term interest rates where they are fixed. Some countries propose mixed mortgage rates where the mortgage rate is fixed for the first few years and adjustable for the rest of the term. In recent years, the very low level of interest rates has generally led households to lock into fixed interest rate debt contracts. In our sample countries, adjustable rates remain dominant in countries with MEW.

Maximum observed LTV, in column 5, refers to the country-specific upper LTV limit (in general legal limits). They can serve as a proxy for borrowing constraints (especially for new borrowers). Most countries are in the 70-80 and 90-100 LTV buckets. High LTV limits tend to be associated with deeper mortgage markets but may also result in increased risks, in particular when they are associated with excessively rapid house-price and credit growth in boom periods.

Finally, the term to maturity (column 6) is on average around 25 years in our sample, although in some countries, such as Ireland and Sweden, it is over 40 years. Such high terms may reflect differences in home affordability.

The interaction between these various structural and local features should lead to very different economic patterns in both the borrowing capacity of households and the resilience of housing markets.

Regarding household debt, Fig. 6.5 clearly shows a significant difference between, on the one hand, countries where households can cash in their mortgage equity, where interest rates are mostly adjustable and LTV ratios are high (AngloSaxon and Nordic countries), and on the other continental European countries where debt levels are significantly lower. The difference is particularly striking in the 
150

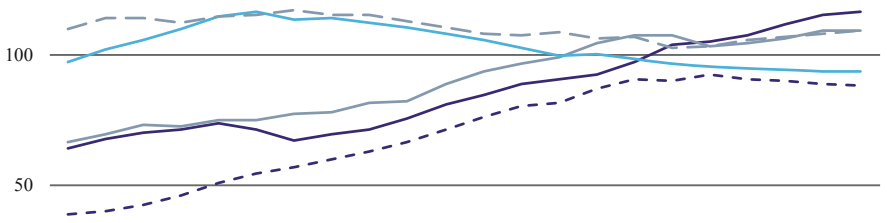

$\begin{array}{lllllllllll}1995 & 1997 & 1999 & 2001 & 2003 & 2005 & 2007 & 2009 & 2011 & 2013 & 2015\end{array}$

Belgium France

- Germany - - - Italy

$400 \longrightarrow$

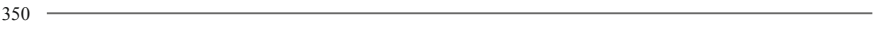

300
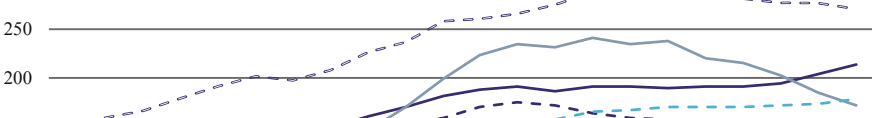

$150 \ldots+\infty$

100
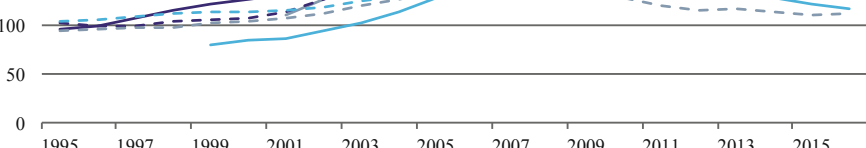

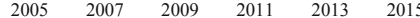

- Australia $\quad$ Ireland

- Spain - - - United Kingdom

--- United States $\quad---$ Canada

- - Netherland

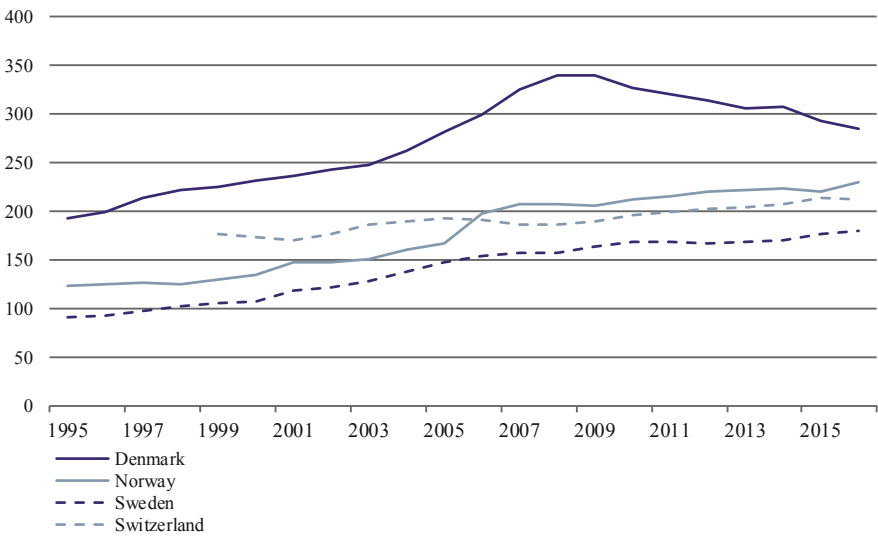

Source: OECD (2018a)

Fig. 6.5 Household debt as a percentage of net disposable income 


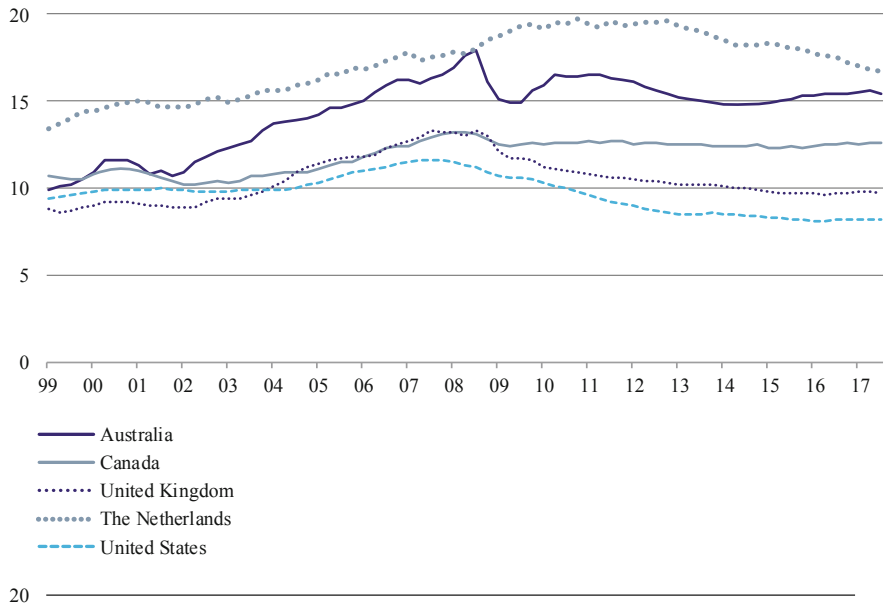

15

10

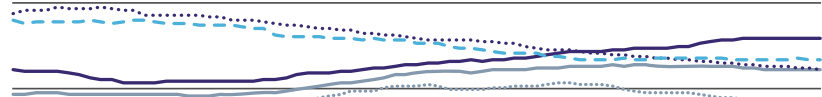

5 $\begin{array}{lllllllllllllllllll}09 & 00 & 01 & 02 & 03 & 04 & 05 & 06 & 07 & 08 & 09 & 10 & 11 & 12 & 13 & 14 & 15 & 16 & 17\end{array}$

\begin{tabular}{l}
\hline Belgium \\
- France \\
.......... Germany \\
…..... Italy \\
- - - Japan
\end{tabular}

20
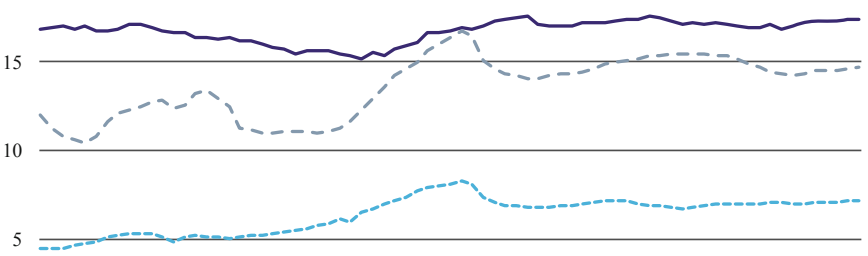

0

$\begin{array}{lllllllllllllllllll}99 & 00 & 01 & 02 & 03 & 04 & 05 & 06 & 07 & 08 & 09 & 10 & 11 & 12 & 13 & 14 & 15 & 16 & 17\end{array}$

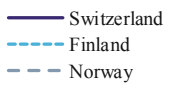

Source: Bank for International Settlements (2018b)

Fig. 6.6 Debt service ratios for the household sector 
run-up to the crisis, less so afterwards, due to the deleveraging process that took place in many countries in the first group.

Similar conclusions can be drawn from the developments in debt service ratios presented in Fig. 6.6, both in terms of debt-service levels and dynamics. Continental European countries are characterised by significantly lower debt service ratios. Here again, the predominance of fixed mortgage rates, which are generally associated with lower LTV limits and a limited ability for households to relax their borrowing constraints, has certainly contained the house price boom while at the same time maintaining the resilience of the household sector. However, the incentives to deleverage have certainly been reduced and have led to a continuous increase in the debt level of households in countries such as France or Belgium, which could lead at some point to concerns regarding their sustainability.

\section{Policy Implications}

The low level of interest rates and the very favourable financial conditions have renewed financial stability concerns. In several countries, a decoupling can clearly be seen between house prices on the one hand and rents and income on the other.

Figures 6.7 and 6.8 respectively show changes in price-to-rent and price-toincome ratios over time and across countries. While the general trend is that of an increase in the price-to-rent ratio and a decrease in the price-to-income ratio, several countries are experiencing a sharp increase in both ratios, notably Australia, Canada, New Zealand, Norway and Sweden.

Real house prices in these countries are well above historical levels, and are also currently growing much faster than their long-term trend. In addition, house prices in their big cities are overshooting national developments. In all of these countries, household debt, which was already fairly high, has been increasing steadily and the pace of growth has even accelerated in Australia.

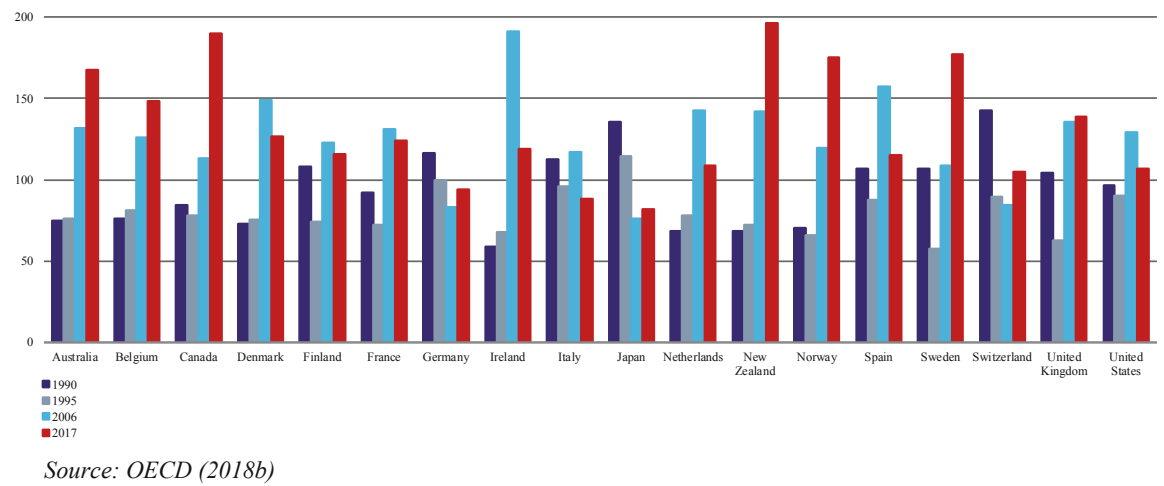

Fig. 6.7 Price-to-rent ratios in selected OECD countries 


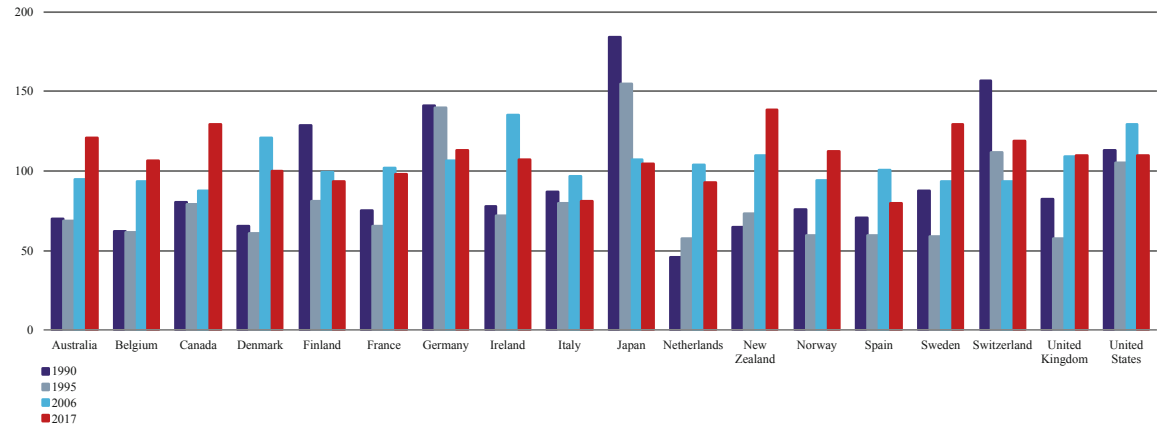

Source: OECD (2018b)

Fig. 6.8 Price-to-income ratios in selected OECD countries

Despite the increasing synchronicity in housing cycles at the global level, the fact that domestic structural features continue to play a significant role in shaping house price dynamics and explain the differences observed in the amplitude of housing cycles is reassuring for national authorities.

It means that they still have some leeway both to counteract cyclical developments in their housing markets and to insulate their economies from global financial shocks by resorting to active macroprudential policies. Sweden and Norway have already activated their countercyclical buffers, while other countries have tightened their LTV limits (Finland, Ireland, Netherlands and Norway) or their loan-to-income limits, as in the UK. Alternatively, Canada started to increase its key policy rates last year without resorting, as yet, to macroprudential policy to contain credit expansion.

This last example points to the fact that macroprudential policy can be used in coordination with other policies: monetary policy, which can affect domestic financial conditions and curb credit growth; and fiscal policies, with the removal of fiscal incentives associated with mortgage debt or the adoption of fiscal policies to encourage housing supply. The value added of macroprudential policy in this context is not only that it can be used to "lean against the wind" but also that it can increase the resilience of financial institutions by raising their loss absorption capacity or reducing their exposure to risky borrowers. It also allows for a more targeted policy.

\section{References}

Airbnb. Accessed April 1, 2018, from https://www.airbnb.com/ ATKearney. (2017). Global cities 2017: Leaders in a world of disruptive innovations.

Bank for International Settlements. (2018a). Residential property prices. Accessed April 1, 2018, from https://www.bis.org/statistics/pp_selected.htm?m=6\%7C288\%7C596

Bank for International Settlements. (2018b). Debt service ratios for the private non-financial sector. Accessed April 1, 2018, from https://www.bis.org/statistics/dsr.htm

Barron, K., Kung, E., \& Proserpio, D. (2017, October 20). The sharing economy and housing affordability: Evidence from Airbnb (NBER working paper). 
Bernanke, B., Gertler, M., \& Gilchrist, S. (1999). The financial accelerator in a quantitative business cycle framework. In J. B. Taylor \& M. Woodford (Eds.), Handbook of macroeconomics (Vol. 1, pp. 1341-1393). Amsterdam: Elsevier.

Borgy, V., Clerc, L., \& Renne, J.-P. (2014). Measuring aggregate risk: Can we robustly identify asset-price boom-bust cycles? Journal of Banking and Finance, 46, 132-150.

Braudel, F. (1984). The perspective of the world. London: Collins.

Cerutti, E., Dagher, J., \& Dell'Ariccia, G. (2017). Housing finance and real-estate booms: A crosscountry perspective. Journal of Housing Economics, 38, 1-13.

Dallas Federal Reserve. (2018). Accessed April 1, 2018, from https://fred.stlouisfed.org/release? rid $=171$

European Systemic Risk Board. (2015, December). Report on residential real estate and financial stability in the EU.

Global Financial Centres Index. (2018). The global financial centres index 23. London: Long Finance.

Gottlieb Duttweiller Institute. (2017). Global city index 2017: The most connected cities.

International Monetary Fund. (2017, April). Are countries losing control of domestic financial conditions? Global Financial Stability Report, Chapter 3, Annex 3.1.

International Monetary Fund. (2018, April). House price synchronization: What role for financial factors? Global Financial Stability Report, Chapter 3.

Kiyotaki, N., \& Moore, J. (1997). Credit cycles. Journal of Political Economy, 105(2), 211-248.

Luo, S., \& Ma, J. (2017). Global housing markets and monetary policy spillovers: Evidence from OECD countries (Working Paper).

Mercer. (2018). Quality of living rankings 2017. Accessed April 1, 2018, from https:// mobilityexchange.mercer.com/Insights/quality-of-living-rankings

Miranda-Agrippino, S., \& Rey, H. (2015). World asset markets and the global financial cycle. NBER Working Paper $\mathrm{N}^{\circ} 21722$.

OECD. (2018a). Household debt. Accessed April 1, 2018, from https://data.oecd.org/hha/house hold-debt.htm

OECD. (2018b). House price indicators. Accessed April 1, 2018, from https://stats.oecd.org/Index. aspx ?DataSetCode $=$ HOUSE_PRICES

Reinhart, C., \& Rogoff, K. S. (2008, December). Banking crises: An equal opportunity menace. NBER Working Paper $\mathrm{N}^{\circ} 14587$.

Rey, H. (2015). Dilemma not trilemma: The global financial cycle and monetary policy independence. IMF Review, 64(1), 6-35.

Taylor, P. J. (2016). Geohistory of globalisation. Protosociology, 33, 131-148.

UBS. (2017). UBS global real estate bubble index.

Wallerstein, I. (1974). The modern world system. New York: Academic Press.

Open Access This chapter is licensed under the terms of the Creative Commons Attribution 4.0 International License (http://creativecommons.org/licenses/by/4.0/), which permits use, sharing, adaptation, distribution and reproduction in any medium or format, as long as you give appropriate credit to the original author(s) and the source, provide a link to the Creative Commons licence and indicate if changes were made.

The images or other third party material in this chapter are included in the chapter's Creative Commons licence, unless indicated otherwise in a credit line to the material. If material is not included in the chapter's Creative Commons licence and your intended use is not permitted by statutory regulation or exceeds the permitted use, you will need to obtain permission directly from the copyright holder.

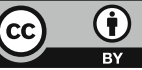

